\title{
Influence of thermo-vacuum treatment on bending properties of poplar rotary-cut veneer
}

\author{
Gaetano Castro ${ }^{(1)}$, Laura Rosso ${ }^{(1)}$, \\ Ottaviano Allegretti ${ }^{(2)}$, Ignazia \\ Cuccui $^{(2)}$, Corrado Cremonini ${ }^{(3)}$, \\ Francesco Negro ${ }^{(3)}$, Roberto \\ Zanuttini $^{(3)}$
}

\begin{abstract}
The present paper investigates the influence of thermo-vacuum treatment at 170,190 and $210{ }^{\circ} \mathrm{C}$ on the mechanical and physical properties of poplar wood rotary-cut veneers obtained from two different poplar clones ('I-214' and 'Lena'). The modulus of rupture in bending was determined according to a method derived from European Standard EN-310 and previously validated by the authors, while the density was determined on the basis of EN-323. With both clones no significant decrease was recorded either in bending strength or in density with treatment temperatures up to $190{ }^{\circ} \mathrm{C}$. On the contrary, at 210 ${ }^{\circ} \mathrm{C}$ a highly significant decrease in modulus of rupture ('I-214': -18\%; 'Lena': $-15 \%$ ) was recorded; the density showed a similar, though lower, trend ('I214': -5 \%; 'Lena': -8.5\%).
\end{abstract}

Keywords: Populus, Poplar Wood, Veneer, Thermal treatment, Bending Strength influence of thermal modification on the color of poplar veneers; Zdravković et al. (2013) assessed the dimensional stability of plywood made of thermally modified poplar veneers.

Several HT processes have been developed during the last years; among these, thermo-vacuum treatment is an innovative technology in which reduction of oxygen concentration, necessary to avoid wood combustion, is obtained by creating a vacuum inside the reactor. This method provides several advantages in terms of process efficiency and quality of the material treated (Allegretti et al. 2012). On the whole, the industrial and scientific interest in thermally treated wood is currently having new impetus due to the growing demand for environmental-friendly construction products (Sandberg et al. 2013, Todaro et al. 2015).

In this paper we report the results of a study on the bending properties of poplar rotary-cut veneers to which a thermo-vacuum process was applied at $170{ }^{\circ} \mathrm{C}, 190{ }^{\circ} \mathrm{C}$ and $210{ }^{\circ} \mathrm{C}$. The aim was to determine which process parameters allow to achieve
(1) C.R.E.A. - Unità di Ricerca per le Produzioni Legnose fuori Foresta, Casale Monferrato, AL (Italy); (2) Università degli Studi di Torino, DISAFA, Torino (Italy); (3) C.N.R. IVALSA, S. Michele all'Adige, TN (Italy)

@ Gaetano Castro (gaetano.castro@crea.gov.it)

Received: Dec 17, 2015 - Accepted: Feb 24, 2016

Citation: Castro G, Rosso L, Allegretti O, Cuccui I, Cremonini C, Negro F, Zanuttini R (2016). Influence of thermo-vacuum treatment on bending properties of poplar rotary-cut veneer. iForest 10: 161-163. - doi: 10.3832/ifor1955-009 [online 2016-06-13] the maximum improvement of performance. In fact, it is well known that while some wood characteristics (e.g., durability, dimensional stability) benefit from thermotreatment, others (e.g., the mechanical behavior) can be negatively influenced (Esteves \& Pereira 2008, Kocaefe et al. 2008).

\section{Materials and methods}

In this experimental work, veneers of the clones ' $\mathrm{I}-214$ ' (Populus $x$ canadensis Moench) and 'Lena' (Populus deltoides W. Bartam. ex Marshall) were peeled by a plywood factory of established experience, according to its usual industrial practice. For each clone, 4 veneers were chosen among the sheets where growth rings and/or separation between sapwood and false heartwood were clearly visible, in order to evaluate the influence of these anatomical features on the properties of the wood material considered. Veneers were divided into different portions, which were subjected to heat treatment at $170{ }^{\circ} \mathrm{C}$ ( $\mathrm{T} 1), 190{ }^{\circ} \mathrm{C}(\mathrm{T} 2), 210{ }^{\circ} \mathrm{C}(\mathrm{T} 3)$; due to the limited amount of material available, treatment $\mathrm{T} 2$ was not performed on the veneers of the clone 'Lena'. Non-treated veneers (To) were also collected and successively tested as control.

After treatment, all veneers, including non-treated ones, were photographed and a grid was drawn on their surface in order to locate all test pieces which were subsequently cut from the sheet and marked according to their original position. From each sheet portion a set of 36 test pieces was drawn.

As there are no international standards establishing mechanical test methods for veneers, the bending strength of the test pieces $(2.5 \mathrm{~mm}$ thick, $20 \mathrm{~mm}$ wide and 80 $\mathrm{mm}$ long) was determined according to a 
Tab. 1 - Clone 'I-214': minimum and maximum values of MoR $\left(\mathrm{N} \mathrm{mm}^{-2}\right)$ and density (in $\mathrm{g}$ $\mathrm{cm}^{-3}$ ), together with standard deviation and mean values, of tested veneers.

\begin{tabular}{llcccc}
\hline Parameter & Statistics & $\begin{array}{c}\text { T0 } \\
\text { (non treated) }\end{array}$ & $\begin{array}{c}\mathrm{T} 1 \\
\left(170{ }^{\circ} \mathrm{C}\right)\end{array}$ & $\begin{array}{c}\mathrm{T} 2 \\
\left(190^{\circ} \mathrm{C}\right)\end{array}$ & $\begin{array}{c}\mathrm{T}^{\circ} \\
\left(210^{\circ} \mathrm{C}\right)\end{array}$ \\
\hline MoR & Min. & 48.39 & 47.73 & 49.95 & 35.21 \\
$\left(\mathrm{~N} \mathrm{~mm}{ }^{-2}\right)$ & Max. & 73.06 & 77.48 & 74.87 & 63.30 \\
& St. dev. & 6.64 & 6.25 & 6.35 & 7.17 \\
& Mean value & 62.14 & 62.75 & 62.82 & 50.97 \\
Density & Min. & 0.290 & 0.299 & 0.297 & 0.281 \\
$\left(\mathrm{~g} \mathrm{~cm}^{-3}\right)$ & Max. & 0.393 & 0.386 & 0.389 & 0.372 \\
& St. dev. & 0.345 & 0.022 & 0.021 & 0.023 \\
& Mean value & 0.345 & 0.340 & 0.342 & 0.329 \\
\hline
\end{tabular}

Tab. 2 - Clone 'Lena': minimum and maximum values of MoR $\left(\mathrm{N} \mathrm{mm}^{-2}\right)$ and density (in $\mathrm{g} \mathrm{cm}^{-3}$ ), together with standard deviation and mean values, of tested veneers.

\begin{tabular}{llccc}
\hline Parameter & Statistics & $\begin{array}{c}\text { T0 } \\
\text { (non treated) }\end{array}$ & $\begin{array}{c}\mathrm{T} 1 \\
\left(\mathbf{1 7 0}{ }^{\circ} \mathbf{C}\right)\end{array}$ & $\begin{array}{c}\text { T3 } \\
(\mathbf{2 1 0}\end{array}$ \\
\hline MoR & Min. & 45.83 & 48.46 & 26.15 \\
$\left(\mathrm{~N} \mathrm{~mm}^{-2}\right)$ & Max. & 83.60 & 76.71 & 76.65 \\
& St. dev. & 9.84 & 7.08 & 11.52 \\
& Mean value & 61.05 & 62.28 & 51.99 \\
\hline Density & Min. & 0.304 & 0.314 & 0.292 \\
$\left(\mathrm{~g} \mathrm{~cm}^{-3}\right)$ & Max. & 0.465 & 0.471 & 0.451 \\
& St. dev. & 0.041 & 0.038 & 0.046 \\
& Mean value & 0.398 & 0.386 & 0.364 \\
\hline
\end{tabular}

method - based on EN-310 (1994) - already validated by one of the authors in a previous study (Castro et al. 2014). Due to the high correlation between modulus of elasticity $(\mathrm{MoE})$ and modulus of rupture (MoR) demonstrated (Castro et al. 2014), and in consideration of the simplicity and convenience of determining the latter with the equipment available, only MoR was measured.

The test pieces were conditioned until constant mass was reached in a climatic cell at a temperature of $20 \pm 2{ }^{\circ} \mathrm{C}$ in an atmosphere with $65 \pm 5 \%$ of relative humidity and then subjected to three-point static bending (with a span of $70 \mathrm{~mm}$ ), to determine their longitudinal Modulus of Rupture (MoR). The tests were carried out using a tensometer particularly suitable for smallsize test pieces when the strains to be measured are rather low, by means of a $100 \mathrm{daN}$ load cell. The load was applied with a constant movement rate of the loading head of $5 \mathrm{~mm} \mathrm{~min}^{-1}$, corresponding to a total time until rupture between $90 \mathrm{~s}$ and $120 \mathrm{~s}$.

As for the determination of density, the tests were carried out in conformity with EN-323 (1994) standard. The dimensions of each test piece were measured using a digital caliper with an accuracy of $\pm 0.01 \mathrm{~mm}$, while the weight was measured using a scale with an accuracy of $\pm 0.01 \mathrm{~mm}$.

For both MoR and density, statistical differences among treatments To, T1, T2 and T3 were investigated through the analysis of variance (ANOVA) using a LSD post-hoc test.

\section{Results and conclusions}

Tab. 1 and Tab. 2 report minimum and maximum values, together with standard deviations and mean values, of the bending strength and density determined on test pieces of the clones ' $1-214$ ' and 'Lena' respectively, cut both from veneers subjected to all treatments and from nontreated ones.

According to previous researches (Castro et al. 2014), it can be easily seen that the bending strength varies significantly in the different zones of the growth ring. The values determined on early wood are considerably lower than those obtained on latewood: for instance, in the case of 'I-214' non-treated (To) veneers the minimum value $\left(48.4 \mathrm{~N} \mathrm{~mm}^{-2}\right)$, recorded on early wood, is only $43 \%$ of the maximum value $\left(73.1 \mathrm{~N} \mathrm{~mm}^{-2}\right)$ obtained on latewood. Similar differences were also found for all the treatments for both clones.

Either for MoR or density, no significant difference was found for both clones among non-treated veneers and veneers treated at $170^{\circ} \mathrm{C}$ and $190^{\circ} \mathrm{C}$. Instead, statistically significant differences $(p<0.01$ for MoR and $p<0.05$ for density) were found between veneers treated at $210^{\circ} \mathrm{C}$ and all the other treatments (Fig. 1 and Fig. 2). This behavior, showed both by 'I-214' and 'Lena' veneers, indicates that beyond $190^{\circ} \mathrm{C}$ a relevant degradation of wood fibre structure occurs, determining an abrupt decrease of bending strength properties. Finally, a high and significant correlation was found by linear regression between density and MoR both for 'I-214' $\left(R^{2}=0.88\right)$ and 'Lena' $\left(R^{2}=0.81\right)$, confirming the well-known relation between these parameters.

In conclusion, the results obtained so far suggest that no significant modification in terms of modulus of rupture and density occurs to thermo-vacuum treated poplar
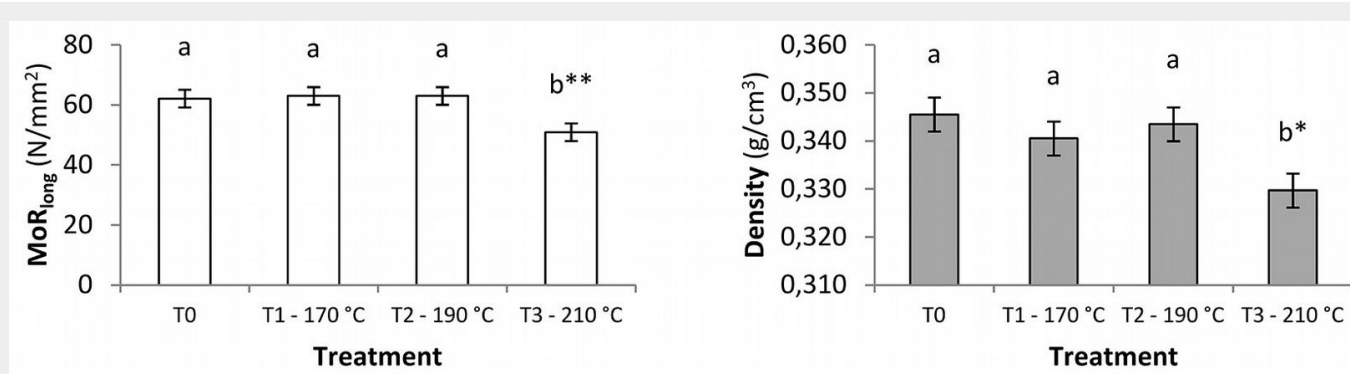

Fig. 1 - Clone 'I-214': mean values and statistical differences MoR (left) and density (right) determined on veneers subjected to $\mathrm{HT}$ To, T1, T2 and T3. Different letters indicate significant differences after LSD test. $(*): p<0.05 ;(* *): p<0.01$
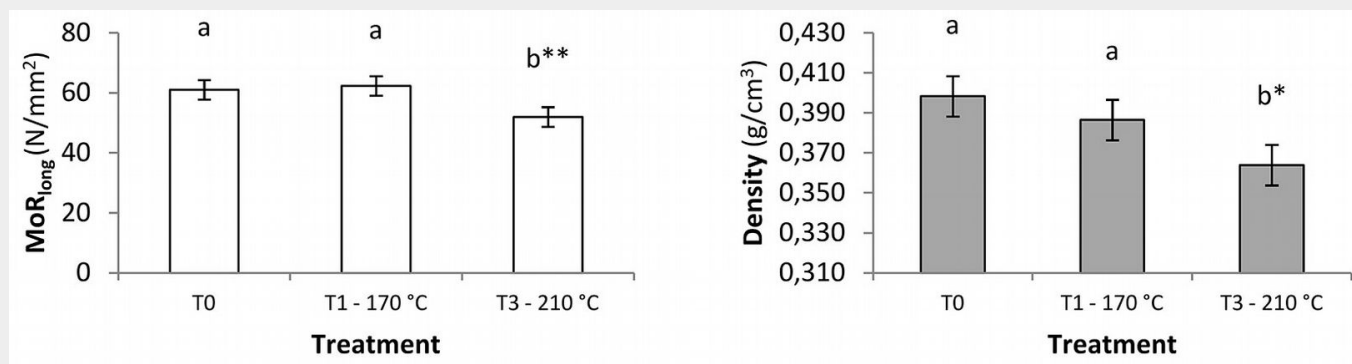

Fig. 2 - Clone 'Lena': mean values and statistical differences MoR (left) and density (right) determined on veneers subjected to $\mathrm{HT}$ To, T1 and T3. Different letters indicate significant differences after LSD test. $(*): p<0.05 ;(* *): p<0.01$. 
veneers up to $190{ }^{\circ} \mathrm{C}$, while at $210{ }^{\circ} \mathrm{C}$ these properties decrease significantly. These findings, together with other data on treated veneers such as natural durability and dimensional stability, could allow to develop an effective thermo-vacuum treatment for poplar veneers and plywood. Such a product could be suitable for many applications in exterior environments, particularly as a replacement for panels made with some exotic wood species.

\section{Acknowledgements}

This research was part of the project "ThermoPoplarPly", jointly financed by the European Union, the Italian State and the Piedmont Region under the Rural Development Programme 2007-2013.

\section{References}

Allegretti O, Brunetti $M$, Cuccui I, Ferrari S, Nocetti M, Terziev N (2012). Thermo-vacuum modification of spruce (Picea abies Karst.) and fir (Abies alba Mill.) wood. Bioresources 7 (3): 3659-3669. [online] URL: http://ojs.cnr.ncsu. edu/index.php/BioRes/article/view/BioRes_07_ 3_3656_Allegretti_Thermo_Vacuum_Spruce_Fi $r$

Bekhta P, Niemz P (2003). Effect of high temperature on the change in color, dimensional stability and mechanical properties of spruce wood. Holzforschung 57 (5): 539-546. - doi: 10.1515/HF.2003.080
Castro G, Berti S, Pisano M (2014). Preliminary study on the variation of the bending properties of poplar rotary-cut veneer. European Journal of Wood and Wood Products 72 (6): 837839. - doi: 10.1007/s00107-014-0847-z

EN-310 (1994). Wood based panels. Determination of modulus of elasticity in bending and bending strength. CEN, European Committee for Standardization, Brussels, Belgium, pp. 9. [online] URL: http://standards.cen.eu/dyn/www /f?p=CENWEB:105

EN-323 (1994). Wood based panels. Determination of density. CEN, European Committee for Standardization, Brussels, Belgium, pp. 4. [online] URL: http://standards.cen.eu/dyn/www /f?p=CENWEB:105

Esteves BM, Pereira HM (2008). Wood modification by heat treatment: a review. Bioresources 4 (1): 370-404. [online] URL: http://152.1.0.246/ index.php/BioRes/article/view/BioRes_04_1_\#\# \#\#_Esteves_P_Wood_Mod_Heat_Treatment

Goli G, Cremonini C, Negro F, Zanuttini R, Fioravanti $M$ (2014). Physical-mechanical properties and bonding quality of heat treated poplar ('I214' clone) and ceiba plywood. iForest 8: 687692. - doi: 10.3832/ifor1276-007

Kocaefe D, Poncsak S, Boluk Y (2008). Effect of thermal treatment on the chemical composition and mechanical properties of birch and aspen. Bioresources 3 (2): 517-537. [online] URL: http://152.1.0.246/index.php/BioRes/article /view/BioRes_03_2_Kocaefe_PB_ThermalTreat ment_Birch_Aspen
Lovrić A, Zdravković V, Furtula M (2014). Influence of thermal modification on color of poplar (Populus $x$ euramericana) rotary cut veneer. Wood Research 59 (2): 661-670. [online] URL: http://www.researchgate.net/publication/27533 4731

Pétrissans $M$, Gérardin P, El bakali I, Serraj $M$ (2003). Wettability of heat-treated wood. Holzforschung 57 (3): 301-307. - doi: 10.1515/HF.20 03.045

Romagnoli M, Cavalli D, Pernarella R, Zanuttini R, Togni M (2015). Physical and mechanical characteristics of poor-quality wood after heat treatment. iForest 8: 884-891. - doi: 10.3832/ifor1229007

Sandberg D, Haller P, Navi P (2013). Thermohydro and thermo-hydro-mechanical wood processing: an opportunity for future environmentally friendly wood products. Wood Material Science and Engineering 8 (1): 64-88. - doi: 10.1080/17480272.2012.751935

Todaro L, Rita A, Negro F, Moretti N, Saracino A, Zanuttini R (2015). Behavior of pubescent oak (Quercus pubescens Willd.) wood to different thermal treatments. iForest 8: 748-755. - doi: 10.3832/ifor1348-007

Zdravković V, Lovrić A, Stanković B (2013). Dimensional stability of plywood panels made from thermally modified poplar veneers in the conditions of variable air humidity. Drvna Industrija 64 (3): 175-181. - doi: 10.5552/drind.2013. 1223 